\title{
Ashwagandha (Withania somnifera) and Their Effects on the Reproductive Hormones of Male Rats
}

\author{
Hend M. Ali \\ Assistant Prof., Nutrition and Food Science \\ Home Economics Department, Faculty of Specific Education, Assiut \\ University, Egypt
}

\begin{abstract}
Effect of Ashwagandha (powder, extract and their mixtures) on feed intake, body weight gains, feed efficiency ratio, lipid profile, liver enzymes, kidney functions and fertility hormones in rats were examined. Forty-two adult male rats weighing $(115 \pm 5 \mathrm{~g})$ were divided into 2 main groups. The first main group fed on basal diet as a (negative control group) consisted of (7) rats, while the second main group consisted of (35) rats divided into five similar subgroups were injected with sodium valproate to induce testicular injury at a dose (500 $\mathrm{mg} / \mathrm{kg}$ ) body weight. The first subgroup was then maintained as positive control $(+\mathrm{Ve})$, the second subgroup was fed on basal diet plus Ashwagandha powder $(100 \mathrm{~g} / \mathrm{kg} \mathrm{diet})$, the third subgroup was fed on basal diet plus Ashwagandha extract $(10 \mathrm{mg} / \mathrm{kg}$ b.w/rat) orally, the fourth subgroup was fed on basal diet plus L-carnitine $(150 \mathrm{mg} / \mathrm{kg}$ b.w/rat) orally, the fifth subgroup was fed on basal diet plus Ashwagandha powder and (Ashwagandha extract \& L-carnitine/rat orally) for one month. At the end of the experimental period, blood samples were collected from each rat and separate the serum which used for determination of some biochemical analysis. Tests specimens were taken for examination. The results of Ashwagandha powder, extract and combination orally to rats revealed that non-significant differences in body weight gains, feed efficiency ratio, feed intake and decreased serum lipid profile and increased in HDL-c. It also decreased in liver enzymes, kidney functions and fertility hormones serum Testosterone, Follicle Stimulating Hormone, Lutenizing Hormone in induced rats which feed on combination of Ashwagandha powder, extract and Lcarnitine. So this study recommended using Ashwagandha in improving fertility for patients.
\end{abstract}

Keywords

Ashwagandha, Rats, Fertility Hormones, Lipids profile, Liver enzymes, Kidney functions, Biochemical analysis. 


\section{INTRODUCTION}

Ashwagandha (Withania somnifera Dunal) belonging to Solanaceae family is a small woody shrub or herb that grows to usually 30 to $50 \mathrm{~cm}$ height (maximum of $150 \mathrm{~cm}$ ) Sapra et al., (2020). It is an adoptogenic herb and its roots, seeds and leaves are used in ayurvedic and unani medicines to promote "youthful vigor," enhance muscle strength and endurance, and improve overall health Kulkarni and Dhir (2008).

Ashwagandha, also known as Withania somnifera, Indian ginseng and winter cherry, has been an important traditional herbal medicine for over 3000 years Mishra et al., (2005).

The extract of (W. somnifera) is a complex mixture of a large number of phytochemicals including phenolic compounds and flavonoids. However, the pharmacological effect of the roots of $W$. somnifera is attributed to withanolides Udayakumar et al., (2010) . Polyphenols are the biggest group of phytochemicals, and many of them have been found in plant-based foods. Polyphenols have been found to be strong antioxidants that can neutralize free radicals by donating an electron or hydrogen atom Rice-Evans et al., (2000). In addition to radical scavenging, polyphenols chelate metal ions such as $\mathrm{Fe}+2$ directly and reduce the rate of Fenton reaction, thus preventing oxidation caused by highly reactive hydroxyl radicals Perron and Brumaghim (2009).

The extract of the Ashwagandha root has many biological implications due to its diverse phytochemicals Dar et al., (2015), so it has been used, singly or in combination with other natural plants, in many research studies for its properties: anti-diabetic Chukwuma et al., (2019), anti-inflammatory Sun et al., (2016), anti-microbial Tripathi et al., (2018), anti-tumor Hassannia et al., (2019), anti-stress Kaur et al., (2001), cardioprotective Kaur et al., (2015), or neuroprotective Yenisetti et al., (2016). It also displays enhanced endothelial function Dar et al., (2015), reduces reactive oxygen species Sun et al., (2016), regulates apoptosis Ahmed et al., (2018), and modulates mitochondrial function Dar et al., (2015), showing to be effective to treat aging effects Pradhan et al., (2017), cognitive functions and memory Choudhary et al., (2017), skin diseases Li et al., (2016) and thyroid function, Sharma et al., (2018),

Ashwagandha has the antioxidant property that can reduce free radicals induced oxidative stress; Singh et al., (2002); Mishra $\left(\mathbf{2 0 0 9}^{\mathrm{a}}\right)$ and Bhattacharya at al., (2010). Thus, some of the useful effects of dietary intake Ashwagandha roots on triglyceride level are attributable to the reduction of stress oxidative and lipid peroxidation.

hormones regularly occur as men age. After the age of 40, as an average males experience a decrease in testosterone levels at the rate of $1 \%-2 \%$ per 
annum Stanworth and Jones, (2008). Dehydroepian- drosterone sulfate (DHEA-S) concentrations also decline by an average of $1 \%-4 \%$ per year between the ages of 40 and 80 Walther et al., (2016). Testosterone and DHEA have several important roles in the body as they affect sexual health, lean body mass, mental health, cognition, bone density, cardiovascular function, and metabolic activity, just to name a few Kelly and Jones (2013) and Rutkowski et al., (2014). Testosterone can be turned by the enzyme aromatase into estradiol. Estradiol is a hormone that is usually associated with females, it also drops down as men age Orwoll et al., (2006). It has several crucial roles in males, which involves a crucial impact in male sexual function, levels of adiposity, neurological activity, immunity and cardiovascular health Schulster et al., (2016) and Cooke et al., (2017).

Adding aqueous extract of Ashwagandha had a huge effect. As the FSH serum level declined and LH level increased in rats Abdel-Magied et al., (2001). Besides, it has been proven that this administration had a major impact in men as both serum and LH levels increased \& FSH levels decreased Ahmad et al., (2009). Furthermore, some studies have shown that aqueous extract of Ashwagandha causes some hypophysial gonadotropines to change as well as sperms in male rats and foliclegenesis in immature female rats to increase $\mathbf{A l}$ Qarawi et al., (2011).

This study was conducted to investigate the effect of the Ashwagandha (Withania somnifera) and their effects on the reproductive hormones of male rats.

\section{Materials}

\section{Materials and Methods}

-Ashwagandha was obtained from Agriculture Research Center, Dokki, Giza, Egypt.

- Casein, cellulose, choline chloride powder, vitamins, minerals, DL methionine powder, L-Carnitine and Sodium valproate were purchased from El-Gomhoria Company for chemical, Drugs and Medical Instruments, Assiut, Egypt. Oil and corn starch were obtained from local market in Assiut, Egypt. The kits were supplied by Bio Diagnostics Company Cairo, Egypt.

- Forty-two adult male albino rats Sprague Dawley strain weighing $(115 \pm 5 \mathrm{~g})$ were obtained from the animal house of the Faculty of Medicine, Assiut University. 


\section{Methods}

\section{Preparation of Ashwagandha extract}

Ashwagandha was prepared daily as tea by steeping in boiling water for 5 minutes. It was given to rats at dose $(10 \mathrm{mg} / \mathrm{kg}$. Bwt $/ \mathrm{rat})$.

\section{Scavenging effect on 2, 2-diphenyl-1-picrylhydrazyl (DPPH) radicals}

The effect of Ashwagandha on DPPH radical was studied, employing the modified method described earlier by Yamaguchi et al., (1998). Briefly, 1.5 $\mathrm{ml}$ of DPPH solution $(0.1 \mathrm{mM}$, in $95 \%$ Ethanol) was incubated with varying concentrations of the extract (Ashwagandha, 0.75 - $5.0 \mathrm{mg}$ ). The reaction mixture was shaken well and incubated for $20 \mathrm{~min}$ at room temperature and the absorbance of the resulting solution was read at $517 \mathrm{~nm}$ a gains a blank. The radical scavenging activity was measured as a decrease in the absorbance of $\mathrm{DPPH}$ and was calculated using the following equation:

A Sample $(517 \mathrm{~nm}) \times 100$

Scavenging effect $\%=$

\section{Experimental design}

A Control $(517 \mathrm{~nm})$

Forty-two adult male albino rats, weighing $115 \pm 5 \mathrm{~g}$ were used in the study. The animals were obtained from the animal house of the Faculty of Medicine, Assiut University, Rats were housed in individual stainless steel cages under controlled environmental conditions, in the animal house and fed one week on basal diet according to Reeves et al., (1993). After the adaptation period, the experimental animals were divided into 2 main groups. The first main group fed on basal diet as a (negative control group) consisted of (7) rats, while the second main group consisted of (35) rats divided into five similar subgroups were injected with sodium valproate to induce testicular injury as described by Bairy et al., (2010) at a dose $(500 \mathrm{mg} / \mathrm{kg})$ body weight. The first subgroup was then maintained as positive control $(+\mathrm{Ve})$, the second subgroup was fed on basal diet plus Ashwagandha powder $(100 \mathrm{~g} / \mathrm{kg}$ diet $)$, the third subgroup was fed on basal diet plus Ashwagandha extract $(10 \mathrm{mg} / \mathrm{kg} \mathrm{b} . \mathrm{w} / \mathrm{rat})$ orally, the fourth subgroup was fed on basal diet plus L-carnitine $(150 \mathrm{mg} / \mathrm{kg}$ b.w/rat) orally, the fifth subgroup was fed on basal diet plus Ashwagandha powder and (Ashwagandha extract \& L-carnitine / rat orally) for one month.

During the experimental period (30 days), each rat was weighed every week and food consumption was recorded. The body weight gain \% (BWG\%) and food efficiency ratio (FER) were estimated outlined by Chapman et al., (1959). At the end of the experimental period rats were fasted over night before sacrificing blood was collected then centrifuged serum was separated and stored at $-20^{\circ} \mathrm{C}$ for biochemical analysis. 
Biochemical Analysis

Lipids profile

Serum total cholesterol (TC), triglycerides (TG), high density lipoprotein (HDL-c), low density lipoprotein (LDL-c) and very low density lipoprotein (VLDL-c) were determined according to the colorimetric method described by Roeschlau et al., (1974) \& Fossati and Principe, (1982).

Calculation of very low density lipoprotein cholesterol (VLDL-c)

VLDL-c was calculated in $\mathrm{mg} / \mathrm{dl}$ according to Lee and Nieman (1996) was using the following formula:

VLDL-c $(\mathrm{mg} / \mathrm{dl})=$ Triglycerides $/ 5$

Determination liver functions

Determination of serum alanine amino transferase (ALT), serum asparatate amino transferase (AST), serum alkaline phosphatase (ALP) were carried out according to the method of Hafkenscheid (1979); Clinica Chimica Acta (1980) and Moss (1982); respectively.

Determination of kidney functions

Serum urea and serum creatinine were determinate by enzymatic method according to Henary (1974); Patton and Crouch (1977) \& Han et al., (1984).

\section{Determination of serum fertility hormones}

Testosterone (T), Lutenizing Hormone (LH) and Follicle Stimulating Hormone (FSH) were determined according to the method of Maruyama, (1987).

\section{Determination of the gonadosomatic Index}

The body weight of each rat was determined immediately before sacrificing. After sacrifice and dissection, the testes were removed, and individual testes were weighed to determine the gonadosomatic index according to the method of Anderson et al., (1983).

Tissue sampling for biochemical analysis

Immediately after weighing the genitalia, each testis was homogenized for the biochemical analysis of antioxidant enzymes, including superoxide dismutase activity (SOD), glutathione activity (GSH) were determined according to Beutler et al., (1963) and Nishikimi et al., (1972); respectively.

\section{Statistical analysis}

The obtained data were statistically analyzed using computerized SPSS, (1988). Effects of different treatments were analyzed by one way ANOVA (Analysis of variance) test using Duncan's multiple range test and $p<0.05$ was used to indicate significance between different groups as described by Snedecor and Cochran (1967). 


\section{Results and Discussion}

(DPPH) radical scavenging activity \% of Ashwagandha extract was shown in Table (1). The measured radical scavenging activity $\%$ of Ashwagandha extract were 59.73, 87.46, 90.43 and 96.06; respectively

DPPH is a stable free radical that easily accepts an electron or hydrogen, when an antioxidant reducing agent reacts with the DPPH which converts it to $\alpha, \alpha-$ diphenyl- $\beta$ picryl hydrazine and solution losses its colour depending upon the number of electrons taken up Shahriar et al., (2013). The radical scavenging activity of Withania somnifera in the present study was similar to the reports of Kumar et al., (2018). Who found radical scavenging activity could be due to content of phenols in the extracts. The antioxidant activity of phenolics is mainly due to their redox properties which make them act as reducing agents, hydrogen donors and singlet oxygen quenchers and also may have a metallic chelating potential Rice-evans et al., (1995).

Data presented in Table (2) show the effect of Ashwagandha powder, extract, L-carnitine and their combination of them on body weight gain, feed intake and feed efficiency ratio on rats. It is clear to notice that, the mean value of body weight gain $(\mathrm{g})$ of positive control group $(+\mathrm{Ve})$ was significantly lower than negative control group (-Ve), which were 55.64 and 101.76 g; respectively. Also, the mean value of treated subgroups 3, 4, 5 and 6 recorded a significant increased in body weight gain, which were 83.59, 85.13, 88.77 and $93.44 \mathrm{~g}$; respectively, with significant difference when compared with positive control $(+\mathrm{Ve})$. The best result were recorded for subgroup (6) which fed on basal diet with Ashwagandha powder, extract and L-carnitine \& combination of them.

As for feed intake and feed efficiency ratio it could be noticed that the mean value of positive control group $(+\mathrm{Ve})$ was significantly lower than that of negative control group, which were $13.94 \& 17.94 \mathrm{~g}$ /day and $0.06 \& 0.10$; respectively. The mean value of treated subgroups 3,4 and 5 indicated nonsignificant differences between them and a significant difference when compared with positive control group $(+\mathrm{Ve})$ which were $16.80,16.66,16.65$ and 0.09, 0.08, 0.09 in feed intake and feed efficiency ratio; respectively. These results are agreement with Malik et al., (2013) who found that the Ashwagandha to improve cardiorespiratory fitness can be the significant effects observed on mitochondrial and energy levels, by reducing the succinate dehydrogenase enzyme activity in the mitochondria and benefiting Mg-ATPase activity Begum and Sadique (1987). Previous studies showed that Ashwagandha significantly enhanced the hemoglobin concentration and red blood cells in animals Ziauddin et al., (1996) and also in humans, with the 
subsequent increase in the capacity to transport oxygen to the muscles. Moreover, it should be considered that Ashwagandha has shown to have antifatigue Mishra (2003) and Biswal et al., (2013) and anti-stress Lopresti et al., (2019) actions.

The effect of Ashwagandha powder, extract, L-carnitine and combination of them on the serum cholesterol, triglyceride, high density lipoprotein (HDL-c), low density lipoprotein (LDL-c) and very low density lipoprotein (VLDL-c) of rats are shown in Table (3). The obtained results showed that the mean value of TC of positive control group $(+\mathrm{Ve})$ was significantly higher the negative control group $(-\mathrm{Ve})$, which were $180.19 \mathrm{mg} / \mathrm{dl}$ and $120.21 \mathrm{mg} / \mathrm{dl}$; respectively. The mean values of treated subgroups $3,4,5$ and 6 were $116.27,117.14,125.48$ and $103.27 \mathrm{mg} / \mathrm{dl}$; respectively and showed a significant difference when compared with positive control group $(+\mathrm{Ve})$.

Concerning triglycerides, results showed that the mean value of serum triglycerides of positive control group $(+\mathrm{Ve})$ was significantly higher than negative control group (-Ve), it was 80.43 and $50.03 \mathrm{mg} / \mathrm{dl}$; respectively. The mean values of treated subgroups 3, 4, 5 and 6 were 55.27, 56.17, 64.32 and $56.19 \mathrm{mg} / \mathrm{dl}$; respectively and showed a significant difference when compared with positive control group $(+\mathrm{Ve})$. The best result was recorded for subgroup (3). These results agreement with Mishra et al., $\left(\mathbf{2 0 0 9}^{b}\right)$ who found that triglyceride level indicate VLDL metabolism decrease in serum triglycerides level is indicative of decreased formation and increased utilization. Ashwagandha per se may have enhancement of triglycerides utilization in the body leading to decrease in its level in serum.

On the other hand, the mean value of HDL-c of positive control group $(+\mathrm{Ve})$ was significantly lower than negative control group (-Ve); it was 14.58 and $46.86 \mathrm{mg} / \mathrm{dl}$; respectively. The mean values of treated subgroups $3,4,5$ and 6 were $34.97,33.60,32.02$ and $31.97 \mathrm{mg} / \mathrm{dl}$ and showed a significant difference when compared with positive control group $(+\mathrm{Ve})$.

As for LDL-c results showed that the mean value for positive control group $(+\mathrm{Ve})$ was significantly higher than negative control group $(-\mathrm{Ve})$, which was 149.52 and $63.34 \mathrm{mg} / \mathrm{dl}$; respectively. The mean values of treated subgroups $3,4,5$ and 6 were $70.25,72.31,80.60 \& 60.06 \mathrm{mg} / \mathrm{dl}$ and showed a significant difference when compared with positive control group $(+\mathrm{Ve})$.

Concerning VLDL-c, results indicated that the mean value of positive control group $(+\mathrm{Ve})$ was significantly higher than negative control group $(-\mathrm{Ve})$. Which were 16.09 and $10.01 \mathrm{mg} / \mathrm{dl}$; respectively. The mean values of treated 
subgroups 3, 4, 5 and 6 were 11.05, 11.23, 12.86 and $11.24 \mathrm{mg} / \mathrm{dl}$ and showed a significant difference when compared with positive control group $(+\mathrm{Ve})$.

Our results are agreement with Anwer et al., (2017) who reported the Withania Somnifera (WS) (200 and $400 \mathrm{mg} / \mathrm{kg}$ ) was administered orally once a day for 5 weeks, resulted in a significant $(\mathrm{P}<0.001)$ reduction in glucose, TC, TG, LDL-c, VLDL-c levels with significant elevation of HDL-c levels.

Jha and Paul (2020) reported that the (Withania Somnifera) at the dose of $1000 \mathrm{mg} / \mathrm{Kg}$ b.w. was orally administered for 4 weeks. The lipid profile study showed inclination in the Total cholesterol level $(117 \pm 6.686 \mathrm{mg} / \mathrm{dl})$, Cholesterol (LDL) $(78.83 \pm 4.151 \mathrm{mg} / \mathrm{dl})$, level and Triglycerides level $(60.83 \pm 2.613 \mathrm{mg} / \mathrm{dl})$, while declination in Cholesterol (HDL) $(13.50 \pm 1.33 \mathrm{mg} / \mathrm{dl})$, level after Endosulfan exposure. But, upon W. somnifera treatment to the endosulfan treated group showed significant $(\mathrm{P}<0.001)$ normalization in the lipid profile levels.

Data given in Table (4) show the mean values of AST liver enzyme level $(\mathrm{u} / \mathrm{l})$ of rats fed on various diets. It could be noticed that the mean values of AST liver enzyme level of control $(+\mathrm{Ve})$ group was higher than control $(-\mathrm{Ve})$ group with a significant difference, it was 193.57 and $80.80 \mathrm{u} / \mathrm{l}$; respectively. All rats fed on various diets, showed significant differences in mean values as compared to control $(+\mathrm{Ve})$ group with a significant difference. The values were 126.86, 123.08, 125.82 and $118.08(\mathrm{u} / \mathrm{l})$; respectively. The best treatment AST liver enzyme level $(\mathrm{u} / \mathrm{l})$ was recorded for subgroup 6 fed on basal diet with combination of Ashwaganha powder, extract and L-carnitine.

Concerning ALT enzyme results indicated that the mean values of positive control group $(+\mathrm{Ve})$ was significantly higher than that of negative control group $(-\mathrm{Ve})$, which was 142.86 and $65.21(\mathrm{u} / \mathrm{l})$; respectively with significant difference. On the other hand, the mean values of treated subgroups fed on Ashwaganha powder, extract, L-carnitine and their combination were lower than positive control group which were 74.76, 72.03, 80.75 and 65.83 $(\mathrm{u} / \mathrm{l})$; respectively. Rats in subgroup (6) fed on combination of L-carnitine and Ashwaganha (powder \& extract) showed non-significant difference as compared with negative control group (-Ve) and recorded the best treatment.

As for ALP enzyme, it could be noticed that the mean value of positive control group (+Ve) was significantly higher than of negative control group ($\mathrm{Ve})$, which were 164.39 and $96.26(\mathrm{u} / \mathrm{l})$; respectively with significant difference. The mean value of treat subgroups $3,4,5$ and 6 were lower than positive control group (+Ve) which were 119.33, 124.74, 128.89 and 114.74 $(\mathrm{u} / \mathrm{l})$; respectively. The best result was recorded for subgroup (6) rats fed on 
combination of Ashwaganha powder, extract and L-carnitine. These results supported by published by Ichikawa et al., (2006) who found Ashwagandha root extract contains withanolides, which have anti-inflammatory property, thus may be helpful in protecting the liver damage and can decrease its weight. Also, Sultana et al., (2012) reported that there were significantly lower levels of serum AST and ALT which come almost normal level in the Ashwagandha pretreated and gentamicin treated rats provides an evidence that, this root extract may have hepatoprotective effects against gentamicin toxicity. All these effects are most likely due to presence of some active ingredients in Ashwagandha root which have antioxidant property.

Data tabulated in Table (5) show the mean value of kidney functions (uric acid, urea and creatinine) level $(\mathrm{mg} / \mathrm{dl})$ of rats fed on various diets. It could be noticed that the mean value of uric acid $(\mathrm{mg} / \mathrm{dl})$ level of positive control group $(+\mathrm{Ve})$ was higher than control negative control group $(-\mathrm{Ve})$, it was 5.20 and $1.53 \mathrm{mg} / \mathrm{dl}$; respectively with a significant difference. All rats fed on various diet, showed significant differences in mean values as compared to control positive (+Ve) group. The values were 2.79, 2.82, 2.07 and $1.98 \mathrm{mg} / \mathrm{dl}$; respectively.

On the other hand, it could be noticed that the mean value of urea $(\mathrm{mg} / \mathrm{dl})$ level of control (+Ve) group was higher than control (-Ve) group, it was 40.93 and $25.88 \mathrm{mg} / \mathrm{dl}$; respectively with a significant difference. All rats fed on various diets, showed significant differences in mean values as compared to control (+Ve) group. The values were 34.14, 31.17, 30.21 and $31.90 \mathrm{mg} / \mathrm{dl}$; respectively. Numerically, the best treatment urea level $(\mathrm{mg} / \mathrm{dl})$ was recorded $30.21 \mathrm{mg} / \mathrm{dl}$ for subgroup (5) fed on basal diet with L-carnitine $(150 \mathrm{mg} / \mathrm{kg})$ when compared to control $(+\mathrm{Ve})$ group.

In case of creatinine level, it could be noticed that the mean value $(\mathrm{mg} / \mathrm{dl})$ of control $(+\mathrm{Ve})$ group was higher than control $(-\mathrm{Ve})$ group, it was being 5.62 and $1.16 \mathrm{mg} / \mathrm{dl}$; respectively with a significant difference. Rats in subgroups $3,4,5$ and 6 fed on variance diet showed significant differences in mean values as compared to control $(+\mathrm{Ve})$ group. The values were 3.87, 2.83, 2.72 and $2.65 \mathrm{mg} / \mathrm{dl}$; respectively. Numerically, the best treatment creatinine level was recorded for subgroup (6) fed on basal diet with combination of Ashwagandha, powder, extract and L-carnitine when compared to positive control group $(+\mathrm{Ve})$. The results are agreement with that obtained by Rahman et al., (2019) who said treated male and female rats of Ashwagandharishta showed a trend of increment (although it was not statistically significant) in the three parameters $0.625,5.0$ and $40.0 \mathrm{ml} / \mathrm{kg}$ of body weight, serum urea, creatinine and uric acid than their corresponding control group. But a 
statistically significant increase was observed in serum urea in all three doses of Ashwagandharishta treated female rats (low: $\uparrow 17.18 \%$, medium: $14.85 \%$ * and high: $\uparrow 24.15 \%, *$. For the serum creatinine level, a statistically significant increase was observed only for the medium dose male rat $(\uparrow 67.979 \% *)$ than their corresponding control group. And no statistically significant increase was observed for the uric acid level.

Data tabulated in Table (6) show the effect of Ashwagandha powder, extract, L-carnitine and combination of them, on the reproductive hormones of male rats. Concerning testis weight $(\mathrm{g} / 100 \mathrm{~g})$, data revealed that the mean value of positive control group $(+\mathrm{Ve})$ was significantly lower than that of the negative control group $(-\mathrm{Ve})$. On the other hand the mean values of subgroups $3,4,5$ and 6 were $1.85,1.95,1.55$ and $1.60(\mathrm{~g} / 100 \mathrm{~g}) ; 0.73,0.72,0.71$ and $0.73 ; 59.33$, $55.25,45.42$ and $60.50\left(10^{6} / \mathrm{ml}\right)$ in testis weight, gonado somatic and sperm number; respectively, which are higher than the positive control $(+\mathrm{Ve})$. Subgroup (4) showed the best result was recorded $1.95 \mathrm{~g} / 100 \mathrm{~g}$ on testis weight and subgroup (5) was 0.71 on gonado somatic when compared with the negative control group (-Ve), while sperm number was 60.50 in subgroup (6) when compared the negative control group $(-\mathrm{Ve})$.

Data in Table (7) showed that positive control group (+Ve) had lower serum testosterone, folicle stimulating hormone and luteinizing hormone when compared with negative control group (-Ve), while subgroup (6) fed on basal diet with combination of Ashwagandha powder, extract and L-carnitine, showed higher values in testosterone, folicle stimulating hormone and luteinizing hormone when compared with the positive control group $(+\mathrm{Ve})$. Our results agreed with Sahin et al., (2016) who said all of the extracts were found to be significantly effective in sexual functioning and antioxidant capacity. Ashwagandha supplementation improves sexual function in male rats via activating Nrf2/ HO-1 pathway while inhibiting the NF- $\mathrm{KB}$ levels.

Low serum testosterone levels in men are strongly related to the increase in morbidity Maggi et al., (2007) and men are commonly in accordance with major depressive disorder Joshi et al., (2010), cardiovascular disease, obesity Di Vincenzo et al., (2018); Traish and Zitzmann (2015), and type 2 diabetes Yao et al., (2018). Lower testosterone concentrations have a negative impact on the quality of life Khera, (2016).

The data given in Table (8) revealed that there were significant differences at $(\mathrm{P}<0.05)$ between positive control group $(+\mathrm{Ve})$ and negative control group $(-\mathrm{Ve})$ these results recorded significant increase in total antioxidant, superoxide dismutase enzymes (SOD) and plasma glutathione transferase (GST) in the negative control group compared with the positive 
control group $(+\mathrm{Ve})$. All treated groups recorded significant increase in these parameters, as compared to the positive control group. These results is agreement with Mishra, (2000) and Singh et al., (2010), which reported that Ashwagandha root contains sitoindosides VIIX and withaferin A, have antioxidant activity by enhancing the free radical scavenging enzymes such as, superoxide dismutase (SOD), catalase (CAT), glutathione peroxidase (GPx).

It has been reported that phenolic compounds show antioxidant properties in vivo via modulation of glutathione (GSH) content, superoxide dismutase (SOD), catalase (CAT) activities, and malondialdehyde equivalent (MDA) Sasidharan et al., (2010). Therefore, phenolic compounds from medical plants can be used as antioxidant agents for preventing, reversing and delaying the occurrence and development of tumors. Flavonoids and phenolic acids all contain hydroxyl groups that play a role in scavenging free radicals. These phenolic compounds were metabolized in vivo via many bio-activating enzymes Jirovsky et al., (2007).

Table (1): Effect (DPPH) radical scavenging activity (\%) of Ashwagandha extract.

\begin{tabular}{|c|c|c|c|c|}
\hline Parameters & 0.5 $\mathbf{~ m g}$ & 1mg & 1.5mg & 2mg \\
\hline DPPH & $59.73 \pm 3.07$ & $87.46 \pm 1.2$ & $90.43 \pm 1.69$ & $96.06 \pm 0.94$ \\
\hline
\end{tabular}

SD: standard Deviation.

Table (2): Effect of Ashwagandha, powder, extract, L-Carnitine and their combination on nutritional parameters of rats.

\begin{tabular}{|c|c|c|c|}
\hline Proups & $\begin{array}{c}\text { Body weight gain } \\
\text { (g) }\end{array}$ & $\begin{array}{c}\text { Feed intake } \\
\text { (g/day) }\end{array}$ & FER \\
\hline Control (-Ve) & $101.76 \pm 8.11 \mathrm{a}$ & $17.94 \pm 2.20 \mathrm{a}$ & $0.10 \pm 0.03 \mathrm{a}$ \\
\hline $\begin{array}{c}\text { Control (+Ve) } \\
\text { Subgroup 1 }\end{array}$ & $55.64 \pm 8.11 \mathrm{~d}$ & $13.94 \pm 2.20 \mathrm{~d}$ & $0.06 \pm 0.06 \mathrm{~d}$ \\
\hline $\begin{array}{c}\text { Ashwagandha powder } \\
\text { (100 } \mathbf{~ m g / k g ) ~} \\
\text { Subgroup 2 }\end{array}$ & $83.59 \pm 6.11 \mathrm{c}$ & $16.80 \pm 2.03 \mathrm{a}$ & $0.09 \pm 0.02 \mathrm{c}$ \\
\hline $\begin{array}{c}\text { Ashwagandha extract } \\
\text { (10 mg/kg) } \\
\text { Subgroup 3 }\end{array}$ & $85.13 \pm 9.13 \mathrm{c}$ & $16.66 \pm 2.32 \mathrm{a}$ & $0.08 \pm 0.04 \mathrm{c}$ \\
\hline $\begin{array}{c}\text { L-Carnitine } \\
\text { (150 mg/kg) } \\
\text { Subgroup 4 }\end{array}$ & $88.77 \pm 9.17 \mathrm{c}$ & $16.65 \pm 2.21 \mathrm{a}$ & $0.09 \pm 0.03 \mathrm{c}$ \\
\hline $\begin{array}{c}\text { L-Carnitine+Ashwagandha } \\
\text { (powder and extract) } \\
\text { Subgroup 5 }\end{array}$ & $93.44 \pm 9.17 \mathrm{~b}$ & $17.68 \pm 2.92 \mathrm{a}$ & $0.09 \pm 0.04 \mathrm{~b}$ \\
\hline
\end{tabular}

Means with different letters in each column are significantly different at $\mathrm{P}<0.05$.

SD: standard Deviation. 
Table (3): Effect Ashwagandha, powder, extract, L-Carnitine and their combination on lipids profile of rats.

\begin{tabular}{|c|c|c|c|c|c|}
\hline Parameters & $\begin{array}{c}\text { TC. } \\
\text { (mg/dl) }\end{array}$ & $\begin{array}{c}\text { TG. } \\
\text { ( mg/dl) }\end{array}$ & $\begin{array}{c}\text { HDL-c } \\
\text { (mg/dl) }\end{array}$ & $\begin{array}{c}\text { LDL-c } \\
\text { (mg/dl) }\end{array}$ & $\begin{array}{c}\text { VLDL-c } \\
\text { (mg/dl) }\end{array}$ \\
\hline Control (-Ve) & $120.21 \pm$ & $50.03 \pm$ & $46.86 \pm$ & $63.34 \pm$ & $10.01 \pm$ \\
& $24.33 \mathrm{a}$ & $12.62 \mathrm{a}$ & $3.11 \mathrm{a}$ & $3.61 \mathrm{a}$ & $0.97 \mathrm{a}$ \\
\hline $\begin{array}{c}\text { Control (+Ve) } \\
\text { Subgroup 1 }\end{array}$ & $180.19 \pm$ & $80.43 \pm$ & $14.58 \pm$ & $149.52 \pm$ & $16.09 \pm$ \\
$12.12 \mathrm{~d}$ & $14.82 \mathrm{~d}$ & $2.54 \mathrm{~d}$ & $7.91 \mathrm{~d}$ & $1.81 \mathrm{~d}$ \\
\hline $\begin{array}{c}\text { Ashwagandha powder } \\
\text { (100 mg/kg) }\end{array}$ & $116.27 \pm$ & $55.27 \pm$ & $34.97 \pm$ & $70.25 \pm$ & $11.05 \pm$ \\
Subgroup 2 & $26.54 \mathrm{~b}$ & $23.03 \mathrm{~b}$ & $2.66 \mathrm{~b}$ & $4.72 \mathrm{~b}$ & $1.01 \mathrm{~b}$ \\
\hline $\begin{array}{c}\text { Ashwagandha extract } \\
\text { (10 mg/kg) }\end{array}$ & $117.14 \pm$ & $56.17 \pm$ & $33.60 \pm$ & $72.31 \pm$ & $11.23 \pm$ \\
Subgroup 3 & $27.65 \mathrm{~b}$ & $24.34 \mathrm{~b}$ & $1.93 \mathrm{~b}$ & $5.13 \mathrm{~b}$ & $1.04 \mathrm{~b}$ \\
\hline $\begin{array}{c}\text { L-Carnitine } \\
\text { (150 mg/kg) }\end{array}$ & $125.48 \pm$ & $64.32 \pm$ & $32.02 \pm$ & $80.60 \pm$ & $12.86 \pm$ \\
Subgroup 4 & $4.28 \mathrm{c}$ & $3.08 \mathrm{c}$ & $2.76 \mathrm{~b}$ & $6.31 \mathrm{c}$ & $1.43 \mathrm{c}$ \\
\hline $\begin{array}{c}\text { L-Carnitine+ } \\
\text { Ashwagandha }\end{array}$ & $103.27 \pm$ & $56.19 \pm$ & $31.97 \pm$ & $60.06 \pm$ & $11.24 \pm$ \\
(powder and extract) & $4.54 \mathrm{~b}$ & $3.46 \mathrm{~b}$ & $2.75 \mathrm{bc}$ & $4.98 \mathrm{a}$ & $1.32 \mathrm{~b}$ \\
Subgroup 5 & & & & & \\
\hline
\end{tabular}

Means with different letters in each column are significantly different at $\mathrm{P}<0.05$.

SD: standard Deviation.

Table (4): Effect of Ashwagandha, powder, extract, L-Carnitine and their combination on liver functions of rats.

\begin{tabular}{|c|c|c|c|}
\hline Proups & $\begin{array}{c}\text { AST } \\
(\mathbf{u} / \mathbf{l})\end{array}$ & $\begin{array}{c}\text { ALT } \\
(\mathbf{u} / \mathbf{l})\end{array}$ & $\begin{array}{c}\text { ALP } \\
(\mathbf{u} / \mathbf{l})\end{array}$ \\
\hline Control (-Ve) & $80.80 \pm$ & $65.21 \pm$ & $96.26 \pm$ \\
& $2.11 \mathrm{a}$ & $1.78 \mathrm{a}$ & $3.97 \mathrm{a}$ \\
\hline Control (+Ve) & $193.57 \pm$ & $142.86 \pm$ & $164.39 \pm$ \\
Subgroup 1 & $5.58 \mathrm{~d}$ & $3.27 \mathrm{~d}$ & $6.49 \mathrm{~d}$ \\
\hline $\begin{array}{c}\text { Ashwagandha powder } \\
\text { (100 mg/kg) }\end{array}$ & $126.86 \pm$ & $74.76 \pm$ & $119.33 \pm$ \\
Subgroup 2 & $4.75 \mathrm{~b}$ & $3.13 \mathrm{~b}$ & $3.65 \mathrm{~b}$ \\
\hline $\begin{array}{c}\text { Ashwagandha extract } \\
\text { (10 mg/kg) }\end{array}$ & $123.08 \pm$ & $72.03 \pm$ & $124.74 \pm$ \\
Subgroup 3 & $4.28 \mathrm{~b}$ & $3.43 \mathrm{~b}$ & $5.65 \mathrm{~b}$ \\
\hline $\begin{array}{c}\text { L -Carnitine } \\
\text { (150 mg/kg) } \\
\text { Subgroup 4 }\end{array}$ & $125.82 \pm$ & $80.75 \pm$ & $128.89 \pm$ \\
\hline $\begin{array}{c}\text { L-Carnitine + Ashwagandha } \\
\text { (powder and extract) } \\
\text { Subgroup 5 }\end{array}$ & $3.02 \mathrm{~b}$ & $2.14 \mathrm{c}$ & $2.62 \mathrm{~b}$ \\
\hline
\end{tabular}

Means with different letters in each column are significantly different at $\mathrm{P}<0.05$.

SD: standard Deviation. 
Table (5): Effect of Ashwagandha, powder, extract, L-Carnitine and their combination on kidney functions of rats.

\begin{tabular}{|c|c|c|c|}
\hline Groups Parameters & $\begin{array}{c}\text { Uric acid } \\
\text { (mg/dl) }\end{array}$ & $\begin{array}{c}\text { Urea } \\
\text { (mg/dl) }\end{array}$ & $\begin{array}{c}\text { Creatinine } \\
\text { (mg/dl) }\end{array}$ \\
\hline Control (-Ve) & $1.53 \pm 0.78 \mathrm{e}$ & $25.88 \pm 4.72 \mathrm{e}$ & $1.16 \pm 1.18 \mathrm{e}$ \\
\hline $\begin{array}{c}\text { Control (+Ve) } \\
\text { Subgroup 1 }\end{array}$ & $5.20 \pm 0.52 \mathrm{a}$ & $40.93 \pm 3.20 \mathrm{a}$ & $5.62 \pm 2.47 \mathrm{a}$ \\
\hline $\begin{array}{c}\text { Ashwagandha powder } \\
\text { (100 mg/kg) } \\
\text { Subgroup 2 }\end{array}$ & $2.79 \pm 0.72 \mathrm{bc}$ & $34.14 \pm 3.29 \mathrm{~b}$ & $3.87 \pm 1.32 \mathrm{~b}$ \\
\hline $\begin{array}{c}\text { Ashwagandha extract } \\
\text { (10 mg/kg) } \\
\text { Subgroup 3 }\end{array}$ & $2.82 \pm 0.57 \mathrm{~b}$ & $31.17 \pm 3.59 \mathrm{c}$ & $2.83 \pm 1.25 \mathrm{c}$ \\
\hline $\begin{array}{c}\text { L-Carnitine (150 mg/kg) } \\
\text { Subgroup 4 }\end{array}$ & $2.07 \pm 0.93 \mathrm{c}$ & $30.21 \pm 3.43 \mathrm{c}$ & $2.72 \pm 1.15 \mathrm{c}$ \\
\hline $\begin{array}{c}\text { L-Carnitine + Ashwagandha } \\
\text { (powder and extract) } \\
\text { Subgroup 5 }\end{array}$ & $1.98 \pm 0.14 \mathrm{~d}$ & $31.90 \pm 2.38 \mathrm{c}$ & $2.65 \pm 0.13 \mathrm{~d}$ \\
\hline
\end{tabular}

Means with different letters in each column are significantly different at $\mathrm{P}<0.05$.

SD: standard Deviation.

Table (6): Effect of Ashwagandha, powder, extract, L-Carnitine and their combination on serum testis weight, gonado somatic and sperm number of rats.

\begin{tabular}{|c|c|c|c|}
\hline Groups & $\begin{array}{c}\text { Testis weight } \\
\text { (g/100g b.wt) }\end{array}$ & $\begin{array}{c}\text { Gonado } \\
\text { somatic } \\
\text { index }\end{array}$ & $\begin{array}{c}\text { Sperm } \\
\text { number } \\
\mathbf{( 1 0 6 / m l )}\end{array}$ \\
\hline Control (-Ve) & $2.22 \pm 0.23 \mathrm{a}$ & $0.68 \pm 0.07 \mathrm{c}$ & $74.25 \pm 18.01 \mathrm{a}$ \\
\hline $\begin{array}{c}\text { Control (+Ve) } \\
\text { Subgroup 1 }\end{array}$ & $1.1 \pm 0.20 \mathrm{~d}$ & $0.40 \pm 0.03 \mathrm{~d}$ & $25.33 \pm 3.09 \mathrm{~d}$ \\
\hline $\begin{array}{c}\text { Ashwagandha powder } \\
\text { (100 mg/kg) } \\
\text { Subgroup 2 }\end{array}$ & $1.85 \pm 0.20 \mathrm{~b}$ & $0.73 \pm 0.07 \mathrm{~b}$ & $59.33 \pm 24.09 \mathrm{~b}$ \\
\hline $\begin{array}{c}\text { Ashwagandha extract } \\
\text { (10 mg/kg) } \\
\text { Subgroup 3 }\end{array}$ & $1.95 \pm 0.26 \mathrm{~b}$ & $0.72 \pm 0.16 \mathrm{~b}$ & $55.25 \pm 15.01 \mathrm{~b}$ \\
\hline $\begin{array}{c}\text { L-Carnitine (150 mg/kg) } \\
\text { Subgroup 4 }\end{array}$ & $1.55 \pm 0.14 \mathrm{c}$ & $0.71 \pm 0.06 \mathrm{~b}$ & $45.42 \pm 20.01 \mathrm{c}$ \\
\hline $\begin{array}{c}\text { L-Carnitine + Ashwagandha } \\
\text { (powder and extract) } \\
\text { Subgroup 5 }\end{array}$ & $1.60 \pm 0.26 \mathrm{c}$ & $0.73 \pm 0.11 \mathrm{~b}$ & $60.50 \pm 14.29 \mathrm{~b}$ \\
\hline
\end{tabular}

Means with different letters in each column are significantly different at $\mathrm{P}<0.05$.

SD: standard Deviation. 
Table (7): Effect of Ashwagandha, powder, extract, L-Carnitine and their combination on serum fertility hormones of rats.

\begin{tabular}{|c|c|c|c|}
\hline Parameter & $\begin{array}{c}\text { T. T } \\
\text { (ng/mL) }\end{array}$ & $\begin{array}{c}\text { FSH } \\
\text { (ng/mL) }\end{array}$ & $\begin{array}{c}\text { LH } \\
\text { (ng/mL) }\end{array}$ \\
\hline Control (-Ve) & $30.2 \pm 1.7 \mathrm{a}$ & $155.38 \pm 6.75 \mathrm{a}$ & $4.9 \pm 0.76 \mathrm{a}$ \\
\hline $\begin{array}{c}\text { Control (+Ve) } \\
\text { Subgroup 1 }\end{array}$ & $16.03 \pm 2.01 \mathrm{~d}$ & $98.17 \pm 7.55 \mathrm{~d}$ & $1.8 \pm 1.16 \mathrm{~d}$ \\
\hline $\begin{array}{c}\text { Ashwagandha powder } \\
\text { (100 mg/kg) } \\
\text { Subgroup 2 }\end{array}$ & $20.12 \pm 3.01 \mathrm{~b}$ & $118.98 \pm 0.65 \mathrm{~b}$ & $2.92 \pm 0.96 \mathrm{c}$ \\
\hline $\begin{array}{c}\text { Ashwagandha extract } \\
\text { (10 mg/kg) } \\
\text { Subgroup 3 }\end{array}$ & $19.33 \pm 14.81 \mathrm{c}$ & $114.42 \pm 0.80 \mathrm{c}$ & $2.54 \pm 0.52 \mathrm{c}$ \\
\hline $\begin{array}{c}\text { L -Carnitine } \\
\text { (150 mg/kg) } \\
\text { Subgroup 4 }\end{array}$ & $21.01 \pm 14.10 \mathrm{~b}$ & $116.60 \pm 0.09 \mathrm{c}$ & $2.47 \pm 0.37 \mathrm{c}$ \\
\hline $\begin{array}{c}\text { L-Carnitine + Ashwagandha } \\
\text { (powder and extract) } \\
\text { Subgroup 5 }\end{array}$ & $25.81 \pm 19.64 \mathrm{~b}$ & $125.59 \pm 0.80 \mathrm{~b}$ & $3.8 \pm 0.96 \mathrm{~b}$ \\
\hline
\end{tabular}

Means with different letters in each column are significantly different at $\mathrm{P}<0.05$.

SD: standard Deviation.

T.T: Testosterone , FSH: Folicle Stimulating Hormone ， LH: Lutenizing Hormone

Table (8): Effect of Ashwagandha, powder, extract, L-Carnitine and their combination on serum total antioxidants, superoxide dismutase and glutathion of rats.

\begin{tabular}{|c|c|c|c|}
\hline Proups & $\begin{array}{c}\text { Total } \\
\text { Antioxidants } \\
\text { (U/mg) }\end{array}$ & $\begin{array}{c}\text { SOD } \\
\text { (U/mg) }\end{array}$ & $\begin{array}{c}\text { GSH } \\
\text { (U/mg) }\end{array}$ \\
\hline Control (-Ve) & $5.4 \pm 0.75 \mathrm{a}$ & $1.67 \pm 0.1 \mathrm{a}$ & $0.14 \pm 0.01 \mathrm{a}$ \\
\hline $\begin{array}{c}\text { Control (+Ve) } \\
\text { Subgroup 1 }\end{array}$ & $1.17 \pm 0.55 \mathrm{~d}$ & $0.33 \pm 0.01 \mathrm{~d}$ & $0.10 \pm 0.01 \mathrm{~d}$ \\
\hline $\begin{array}{c}\text { Ashwagandha powder } \\
\text { (100 mg/kg) } \\
\text { Subgroup 2 }\end{array}$ & $2.98 \pm 0.65 \mathrm{~b}$ & $1.0 \pm 0.04 \mathrm{~b}$ & $0.15 \pm 0.04 \mathrm{ab}$ \\
\hline $\begin{array}{c}\text { Ashwagandha extract } \\
\text { (10 mg/kg) } \\
\text { Subgroup 3 }\end{array}$ & $2.58 \pm 0.80 \mathrm{~b}$ & $1.2 \pm 0.06 \mathrm{~b}$ & $0.13 \pm 0.06 \mathrm{ab}$ \\
\hline $\begin{array}{c}\text { L-Carnitine } \\
\text { (150 mg/kg) } \\
\text { Subgroup 4 }\end{array}$ & $2.61 \pm 0.09 \mathrm{~b}$ & $0.90 \pm 1.10 \mathrm{c}$ & $0.12 \pm 1.10 \mathrm{~b}$ \\
\hline $\begin{array}{c}\text { L-Carnitine + Ashwagandha } \\
\text { (powder and extract) } \\
\text { Subgroup 5 }\end{array}$ & $3.69 \pm 1.80 \mathrm{ab}$ & $1.33 \pm 0.08 \mathrm{ab}$ & $0.18 \pm 0.08 \mathrm{ab}$ \\
\hline
\end{tabular}

Means with different letters in each column are significantly different at $\mathrm{P}<0.05$.

SD: standard Deviation.

SOD: Superoxide dismutase

GSH: Glutathion 


\section{REFERENCES}

Abdel-Magied, E.M.; Abdel-Rahman, H.A. and Harraz, F.M. (2001): The effect of aqueous extracts of Cynomorium coccineum and Withania somnifera on testicular development in immature Wistar rats, J. Ethnopharmacol.,(75):1-4. Ahmad, M.K.; Mahdi, A.A.; Shukla, K.K.; Islam, N.; Rajender, S. and Madhukar, D. (2009): Withania somnifera improves semen quality by regulating reproductive hormone levels and oxidative stress in seminal plasma of infertile males, Fertil. Steril.

Ahmed, W.; Mofed, D.; Zekri, A.R.; El-Sayed, N.; Rahouma, M. and Sabet, S. (2018): Antioxidant activity and apoptotic induction as mechanisms of action of Withania somnifera (Ashwagandha) against a hepatocellular carcinoma cell line, J. Int. Med. Res. (46): 1358-1369.

Al-Qarawi, A.A.; Abdel-Rahman, H.A.; El-Badry, A.A.; Harraz, F.; Razig, N.A. and Abdel-Magied, E.M. (2011): The effect of extracts of Cynomorium coccineum and Withania somnifera on gonadotrophins and ovarian follicles of immature Wistar rats, Phytother. Res.,(14): 288-290.

Anderson; Richard, O.; Gutreuter and Stephen, J. (1983): Chapter 15. Length, weight and assoiated structural indices, In Nielsen, Larry A.; Johnson, David Lawrence (eds.), Fisheries techniques, Bethesda, Md., American Fisheries Society, 283-300.

Anwer, T.; Sharma, M.; Khan, G.; Alam, M. F.; Alam, N.; Ali, Md. S. and Alam, Md. S. (2017): Preventive role of Withania somnifera on hyperlipidemia and cardiac oxidative stress in streptozotocin induced type 2 diabetic rats; Tarique Tropical Journal of Pharmaceutical Research, 16 (1): 119-125.

Bairy, L.; Paul, V. and Rao, Y. (2010): Reproductive toxicity of sodium valproate in male rats, Indian J. Pharmacol, 42(2): 90-94.

Begum, V.H. and Sadique, J. (1987): Effect of Withania somnifera on glycosaminoglycan synthesis in carrageenin-induced air pouch granuloma, Biochem. Med. Metab. Biol., (38): 272-277.

Beutler, E.; Duron, O. and Kelly, M.B. (1963): Determination of reduced glutathione in tissue homogenate, J. Lab. Clin. Med., (61): 882.

Bhattacharya, A.; Ghosal, S. and Bhattacharya, S.K. (2010): Antioxidant effect of Withania somnifera glycowithanolides in chronic footshock stressinduced perturbations of oxidative free radical scavenging enzymes and lipid peroxidation in rat frontal cortex and striatum, J. Ethnopharmacol., (74): 1-6. 
Biswal, B.M.; Sulaiman, S.A.; Ismail, H.C.; Zakaria, H. and Musa, K.I. (2013): Effect of Withania somnifera (Ashwagandha) on the development of chemotherapy-induced fatigue and quality of life in breast cancer patients, Integr. Cancer Ther., (12): 312-322.

Chapman, D. G.; Castilla, R. and Champell, J. A, (1959): Evaluation of protein efficiency ratio, Can. J. Biochem. Physiol., (37): 679-686.

Choudhary, D.; Bhattacharyya, S. and Bose, S. (2017): Efficacy and safety of Ashwagandha (Withania somnifera (L.) Dunal) root extract in improving memory and cognitive functions, J. Diet. Suppl., (14): 599-612.

Chukwuma, C.I.; Matsabisa, M.G.; Ibrahim, M.A.; Erukainure, O.L.; Chabalala, M.H. and Islam, M.S. (2019): Medicinal plants with concomitant anti-diabetic and anti-hypertensive effects as potential sources of dual acting therapies against diabetes and hypertension: a review. J. Ethnopharmacol, (235): 329-360.

Clinica Chimica Acta (1980): (105): 147-172, (Chemical kits).

Cooke, P. S.; Nanjappa, M. K.; Ko, C.; Prins, G. S. and Hess, R. A. (2017): Estrogens in male physiology, Physiological Reviews, 97(3), 995-1043.

Dar, N.J.; Hamid, A. and Ahmad, M. (2015): Pharmacologic overview of Withania somnifera, the Indian Ginseng Cell. Mol. Life Sci.,(72): 4445-4460.

Di Vincenzo, A.; Busetto, L.; Vettor, R. and Rossato, M. (2018): Obesity, male reproductive function and bariatric surgery, Frontiers in Endocrinology, (9): 769.

Fossati, P. and Prencipel, L. (1982): Determination of triglycerides, Clinical Chemistry, (28): 2077-2078

Hafkenscheid, J.C. (1979): Determination of GOT. Clin. Chem., (25): 155.

Han, B.H.; Park, M.H.; Han, Y.N. and Shin, S.C. (1984): Studies on the antioxidant components of Korean ginseng Antifatigue active components, Yakhakhoe Chi., (28): 231-235.

Hassannia, B.; Logie, E.; Vandenabeele, P.; Vanden Berghe, T.; Vanden Berghe, W. and Withaferin A (2019): From ayurvedic folk medicine to preclinical anti-cancer drug, Biochem. Pharm.

Henary, R.J. (1974): Clinical Chemist: principels and Techniques, $2^{\text {nd }}$, Edition, Hagerstoun (MD), Harcer, ROW, 882. 
Ichikawa, H.; Takada, Y.; Shishodia, S.; Jayaprakasham, B.; Nair, MG. and Aggarwal, BB. (2006): Withanolides potentiate apoptosis, inhibits invasion and abolish osteoclastogenesis through suppression of nuclear factorkappa B (NF-B) activation and NF-kappa B- regulated gene expression, Mol. Cancer Ther., 5(6): 1434-1445.

Jha, S. K. and Paul, D. K. (2020): Efficacy of Withania somnifera on lipid profile of endosulfan induced toxicity in swiss albino mice, Journal of Applied and Natural Science, 12(3): $454-459$.

Jirovsky, D.; Kosina, P.; Myslinova, M.; Styskala, J.; Ulrichova, J. and Simanek, V. (2007): HPLC analysis of rosmarinic acid in feed enriched with aerial parts of Prunella vulgaris and its metabolites in pig plasma using dualchannel coulometric detection, J. Agric. Food Chem., (55): 7631-7637.

Joshi, D.; Van Schoor, N. M.; de Ronde, W.; Schaap, L. A.; Comijs, H. C.; Beekman, A. T. and Lips, P. (2010): Low free testosterone levels are associated with prevalence and incidence of depressive symptoms in older men, Clinical Endocrinology, 72(2): 232-240.

Kaur, G.; Singh, N.; Samuel, S.S.; Bora, H.K.; Sharma, S.; Pachauri, S.D.; Dwivedi, A.K.; Siddiqui, H.H. and Hanif, K. (2015): Withania somnifera shows a protective effect in monocrotaline-induced pulmonary hypertension, Pharm. Biol., (53): 147-157.

Kaur, P.; Mathur, S.; Sharma, M.; Tiwari, M.; Srivastava, K.K. and Chandra, R. A. (2001): Biologically active constituent of withania somnifera (ashwagandha) with antistress activity, Indian J. Clin. Biochem., (16): 195-198.

Kelly, D. M. and Jones, T. H. (2013): Testosterone: a metabolic hormone in health and disease, Journal of Endocrinology, 217(3).

Khera, M. (2016): Male hormones and men's quality of life. Current Opinion in Urology, 26(2), 152-157.

Kulkarni, S. K. and Dhir, A. (2008): Withania somnifera: An Indian ginseng. Progress in Neuro-Psychopharmacology and Biological Psychiatry, 32(5): $1093-1105$.

Kumar, K. P.; Reddy, V. R.; Prakash, M. G. and Kumar, K. (2018): In vitro estimation of total phenolics and DPPH radical scavenging activity of Withania somnifera extract, The Pharma Innovation Journal, 7(3): 588-590.

Lee, R. and Nieman, D. (1996): Nutrition Assessment. $2^{\text {nd }}$ Ed. Mosby, Missouri, USA, 591-594. 
Li, W.; Zhang, C.; Du, H.; Huang, V.; Sun, B.; Harris, J.P.; Richardson, Q.; Shen, X.; Jin, R. and Li, G. (2016): Withaferin a suppresses the upregulation of acetyl-coA carboxylase 1 and skin tumor formation in a skin carcinogenesis mouse model., Mol. Carcinog., (55): 1739-1746.

Lopresti, A.L.; Smith, S.J.; Malvi, H. and Kodgule, R. (2019): An investigation into the stress-relieving and pharmacological actions of an ashwagandha (Withania somnifera) extract: a randomized, double-blind, placebo-controlled study, Medicine. (98): 17186.

Maggi, M.; Schulman, C.; Quinton, R.; Langham, S. and UhlHochgraeber, K. (2007): The burden of testosterone deficiency syndrome in adult men: Economic and qualityof-life impact, The Journal of Sexual Medicine, (4): 1056-1069.

Malik, A.; Mehta, V. and Dahiya, V. (2013): Effect of ashwagandha (withania somnifera) root powder supplementation on the vo2 max. and hemoglobin in hockey players, Int. J. Behav. Soc. Mov. Sci., (2): 91-99.

Maruyama, Y. (1987): Sex-steroid binding, plasma protein (SBP), testosterone, estradiol and DHEA in prepuberty and puberty., Acta.Endocrinol., (114): 60-67.

Mishra, L.C. (2000): Scientific basis for the therapeutic use of Withania somnifera (Ashwagandha): a review, Altern Med. Rev., 5(4): 334-346.

Mishra, L.C. (2003): Scientific basis for ayurvedic therapies, CRC Press: Boca Raton, FL., USA.

Mishra, L.C.; Singh, B.B. and Dagenais, S. (2005): Scientific basis for the therapeutic use of Withania somnifera (Ashwagandha): a review. Alternative Medicine Review, (11): 340-346.

Mishra, L.C.; Singh, B.B. and Dagenais, S. $\left(2009^{\mathrm{a}}\right)$ : Scientific basis for the therapeutic use of Withania somnifera (Ashwagandha): a review, Alternative Medicine Review,(5): 334-346.

Mishra, R. K.; Ashok, B. K.; Ravishankar, B. and Pandya, M. A. (2009 ${ }^{\text {b): }}$ Effect of Ashwagandha ghrita and Ashwagandha granules on lipid profile in albino rats, AYU-VOL., (30): $333-336$.

Moss, D.W. (1982): Alkaline Phosphates isoenzyymes, Clin. Chem., (28): 2007- 2016.

Nishikimi, M.; Roa, N.A. and Yogi, K. (1972): Determination of superoxide dismutase in tissue homogenate, Biochem. Bioph. Res.Common., (46): 849 854. 
Orwoll, E.; Lambert, L. C.; Marshall, L. M.; Phipps, K.; Blank, J.; Barrett-Connor, E. and Cummings, S. (2006): Testosterone and estradiol among older men, The Journal of Clinical Endocrinology and Metabolism, 91(4): 1336- 1344.

Patton, C. and Crouch, S. (1977): Determination of serum urea enzymatically, J. Ana. Chem., (49): 464 - 469.

Perron, NR. and Brumaghim, JL. (2009): A review of the antioxidant mechanisms of polyphenol compounds related to iron binding. Cell.

Pradhan, R.; Kumar, R.; Shekhar, S.; Rai, N.; Ambashtha, A.; Banerjee, J.; Pathak, M.; Dwivedi, S.N.; Dey, S. and ; Dey, A.B. (2017): Longevity and healthy ageing genes FOXO3A and SIRT3: Serum protein marker and new road map to burst oxidative stress by Withania somnifera, Exp. Gerontol, (95): $9-15$.

Rahman, T.; Rakib Hasan, Md. and Choudhuri, M. S. K. (2019): Effect of Ashwagandharista (Withania somnifera) on the kidney functions of male and female rats, Jahangirnagar University J. Biol. Sci., 8(1): 1-7,

Reeves, P.G.; Nielson, F.H. and Fahmy, G.C.(1993): Reports of the American Institute of Nutrition, Adhoc Wiling Committee on reformulation of the AIN 93, Rodent Diet. J. Nutri., (123): 1939-1951.

Rice-evans, CA.; Miller, NJ.; Bolwell, PG.; Bramley, PM. and Pridham, JB. (1995): The relative antioxidant activities of plantderived polyphenolic flavonoids, Free radical research, 22 (4): 375-383.

Rice-Evans, CA.; Millerm, NJ. and Paganga, G. (2000): Structureantioxidant activity relationships of flavonoids and phenolic acids, Free Radic. Biol. Med.,(20): 933-956.

Roeschlau, P.; Bernt, E. and Gruber, W. (1974): Enzymatic colorimetric test with lipid clearing factor (LCF), .J. Clin. Chem. \& Clin. Biochem., (12): 403-408.

Rutkowski, K.; Sowa, P.; Rutkowska-Talipska, J.; Kuryliszyn-Moskal, A. and Rutkowski, R. (2014): Dehydroepiandrosterone (DHEA): Hypes and hopes., Drugs, 74(11), 1195-1207.

Sahin, K.; Orhan, C.; Akdemir, F.; Tuzcu, M.; Gencoglu, H.; Sahin, N.; Turk, G.; Yilmaz, I.; Ozercan, I. H. and Juturu, V. (2016): Comparative evaluation of the sexual functions and NF- $\mathrm{KB}$ and $\mathrm{Nrf} 2$ pathways of some aphrodisiac herbal extracts in male rats, BMC., Complementary and Alternative Medicine, (16): 318. 
Sapra, NC.; Kalyanrao, P.; Sasidharan, N.; Arna Das and Susmitha, P. (2020): Effect of mechanical, chemical, growth hormone and biofertilizer treatments on seed quality enhancement in Ashwagandha (Withania somnifera Dunal), Med. Aromat Plants, Los Angeles, Vol. (9): 35.

SAS (1988): SAS Users Guide: Statistics version $5^{\text {th }}$ Ed. SAS., Institute Inc., Cary N.C.

Sasidharan, S.; Aravindran, S.; Latha, L.Y.; Vijenthi, R.; Saravanan, D. and Amutha, S. (2010): In vitro antioxidant activity and hepatoprotective effects of Lentinula edodes against paracetamol-induced hepatotoxicity, Molecules, (15): 4478-4489.

Schulster, M.; Bernie, A. M. and Ramasamy, R. (2016): The role of estradiol in male reproductive function, Asian Journal of Andrology, 18(3): 435-440.

Shahriar, M.; Ismail Hossain, Md.; Sharmin, F. A. Akhter, S.; Haque, Md. A.; Bhuiyan, M. B. and Iosr (2013): Invitro antioxidant and free radical scavenging activity of withania somnifera root, Journal of Pharmacy, Volume (3), 38- 47 .

Sharma, A.K.; Basu, I. and Singh, S. (2018): Efficacy and safety of Ashwagandha root extract in subclinical hypothyroid patients: a double-blind, randomized placebo-controlled trial., J. Altern. Complement. Med., (24): 243248.

Singh, A.; Naidu, P.S.; Gupta, S. and Kulkarni, S.K. (2002): Effect of natural and synthetic antioxidants in a mouse model of chronic fatigue syndrome, J. Med. Food, (5): 211-220.

Singh, G,; Sharma, PK. and Singh, S. (2010): Biological activities of Withania somnifera, Annals of Biological research, 1(3): 56-63.

Snedecor, G.W. and Cochran, W.G. (1967): Statistical Methods. $7^{\mathrm{Ed}}$, the Iowa State University Press, Ames, Iowa, U.S.A.

Stanworth, R. D. and Jones, T. H. (2008): Testosterone for the aging male; current evidence and recommended practice, Clinical Interventions in Aging, 3(1): $25-44$.

Sultana, N.; Shimmi, S. C.; Parash, MT. H. and Akhtar, J. (2012): Effects of Ashwagandha (Withania somnifera) Root Extract On Some Serum Liver Marker Enzymes (AST, ALT) In Gentamicin Intoxicated Rats, J. Bangladesh Soc. Physiol, 7(1): 1-7. 
Sun, G.Y.; Li, R.; Cui, J.; Hannink, M.; Gu, Z.; Fritsche, K.L.; Lubahn, D.B. and Simonyi, A.(2016): Withania somnifera and its withanolides attenuate oxidative and inflammatory responses and up-regulate antioxidant responses in BV-2 microglial cells, Neuromol. Med., (18): 241-252.

Traish, A. M. and Zitzmann, M. (2015): The complex and multifactorial relationship between testosterone deficiency (TD), obesity and vascular disease, Reviews in Endocrine and Metabolic Disorders, 16(3): 249-268.

Tripathi, N.; Shrivastava, D.; Ahmad Mir, B.; Kumar, S.; Govil, S.; Vahedi, M. and Bisen, P.S. (2018): Metabolomic and biotechnological approaches to determine therapeutic potential of Withania somnifera $(L$.) Dunal: a review, Phytomedicine, (50): 127-136.

Udayakumar, R.; Kasthurirengan, S.; Vasudevan, A.; Mariashibu, TS.; Rayan, JJS. And Choi, CW. (2010): Antioxidant effect of dietary supplement Withania somnifera L. reduce blood glucose levels in alloxan-induced diabetic rats, Plant foods for human nutrition, 65(2): 91-98.

Walther, A.; Philipp, M.; Lozza, N. and Ehlert, U. (2016): The rate of change in declining steroid hormones: A new parameter of healthy aging in men? Oncotarget, 7(38): 60844-60857.

Yamaguchi, T.; Takamura, H.; Matoba, T. and Terao, J. (1998): HPLC method for evaluation of the free radical-scavenging activity of foods by using 1,1,-diphenyl-2-picrylhydrazyl, Bioscience Biotechnology Biochemistry,(62): $1201-1204$.

Yao, Q. M.; Wang, B.; An, X. F.; Zhang, J. A. and Ding, L. (2018): Testosterone level and risk of type 2 diabetes in men: a systematic review and meta-analysis, Endocrine Connections, 7(1): 220-231.

Yenisetti, S.C.; Manjunath, M.J. and Muralidhara, C. (2016): Neuropharmacological properties of Withania somnifera - Indian ginseng: an overview on experimental evidence with emphasis on clinical trials and patents, Recent Pat. CNS. Drug Discov, (10): 204-215.

Ziauddin, M.; Phansalkar, N.; Patki, P.; Diwanay, S. and Patwardhan, B. (1996): Studies on the immunomodulatory effects of Ashwagandha, J. Ethnopharmacol, (50): 69-76. 


\section{الملخص العربي}

\section{الأشواجندا وتأثيرها على الهرمونات التناسلية لذكور الجرذان}

نم دراسة تأثير الأشواجندا (مسحوق، مستخلص، خليط منهما) على المأخوذ الغذائي ومعدل كفاءة الغذاء وزيادة وزن الجسم ودهون الدم ووظائف الكبد والكلى وهرمونات الخصوبة في سيرم

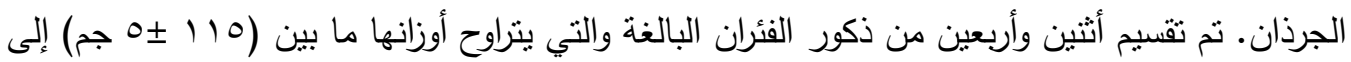

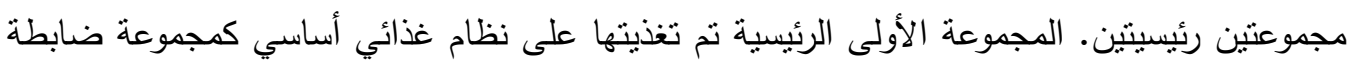

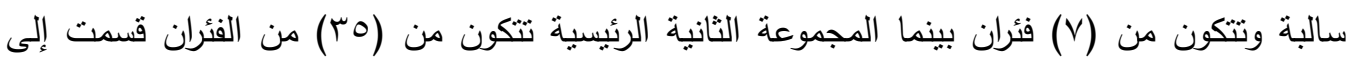

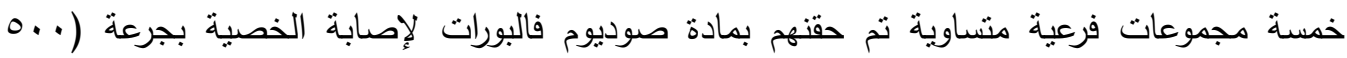

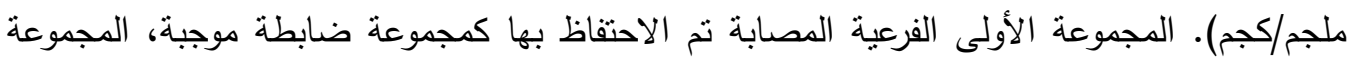
الثانية الفرعية المصابة تم تغذيتها على النظام الغذائي الأساسي مضاف له مسحوق الأشواجندا (...

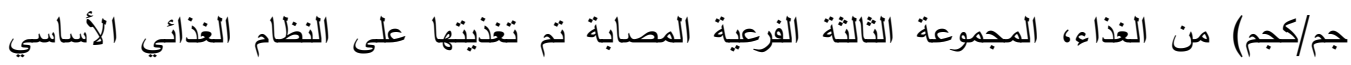
ومستخلص الأشواجندا (•l ملجم/كجم) من وزن الجسم لكل فأر بالفم، المجموعة الرابعة الفرعية تم

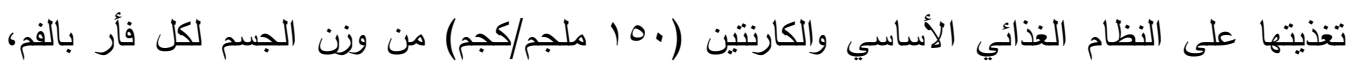

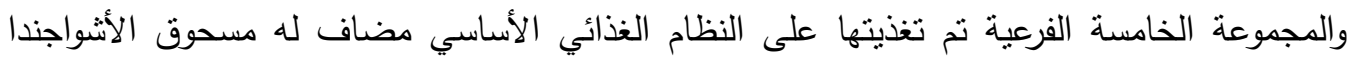

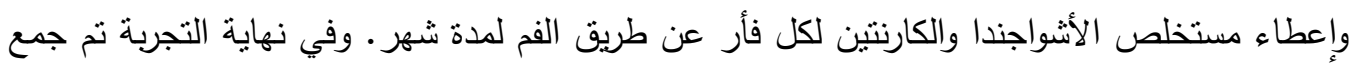

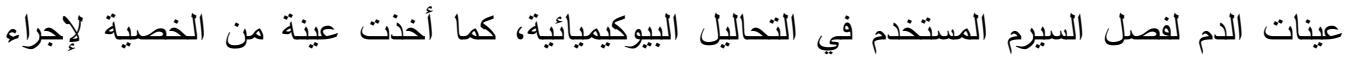

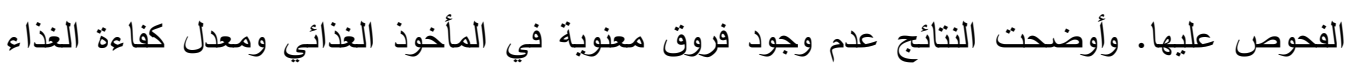

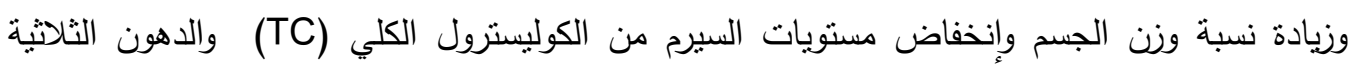

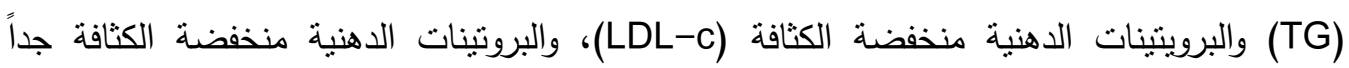

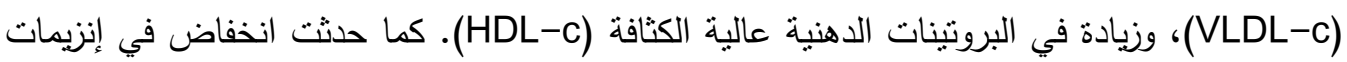
الكبد، ووظائف الكلى. كما زادت هرمونات الخصوبة في السيرم من Testosterone, Follicle Stimulating Hormone, Lutenizing Hormone مسحوق ومستخلص الأشواجندا والكارنتين.

لذا توصي الدراسة باستخدام الأشواجندا لتحسين هرمونات الخيندات الخصوبة للمرضى. الكلمات المفتاحية الأشواجندا، الفئران، هرمونات الخصوبة، دهون الدم، إنزيمات الكبد، وظائف الكلى، التحاليل 